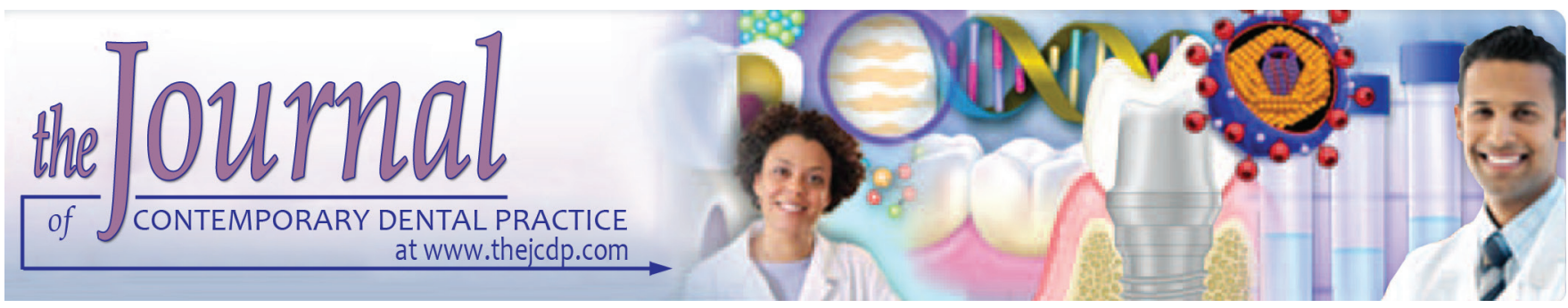

\title{
Evaluation of Hybrid Layer and Bonding Interface after Water Storage with and without the Usage of $2 \%$ Chlorhexidine: A Scanning Electron Microscope Study
}

${ }^{1}$ Anand K Vallabhdas, ${ }^{2} \mathrm{CN}$ Vijay Kumar, ${ }^{3}$ Pradeep Kabbinale, ${ }^{4}$ Rajaram Nayak, ${ }^{5}$ Manju Rajakumari, ${ }^{6}$ Thulasidharan Shilpa

\begin{abstract}
Aim: Restorative dentists employ different bonding systems between the resin and the dentin and other dentinal tissues to achieve the goal of micromechanical retention. Studies have shown that the bond between composite and dentin degrades over time because of the action of matrix metalloproteinases (MMPs) on collagen fibrils left unprotected by acid etching. The MMPs may be partially responsible for hybrid layer degradation. Since chlorhexidine ( $\mathrm{CHX}$ ) inhibits MMPs, we hypothesized that $\mathrm{CHX}$ would decelerate the loss of resin-dentin bonds. Hence, this in vitro study is intended to evaluate the effects of $2 \% \mathrm{CHX}$ on hybrid layer and bonding interface.
\end{abstract}

Materials and methods: Totally, 40 freshly extracted molars were randomly divided into four experimental groups. In all 40 specimens, class II cavities were prepared to a depth of $1 \mathrm{~mm}$ below the dentinoenamel junction with no axial wall, but the elimination of the proximal enamel ridge. The teeth were then randomly divided into four experimental groups, i.e., All Bond 2 without $2 \% \mathrm{CHX}$ (group I), All Bond 2 with $2 \%$ $\mathrm{CHX}$ (group II), One Coat 7.0 without $2 \% \mathrm{CHX}$ (group III), and One Coat 7.0 with $2 \% \mathrm{CHX}$ (group IV). All the specimens were derooted and sectioned mesiodistally into two halves and placed under water at $37^{\circ} \mathrm{C}$ for 3 months and observed under scanning electron microscope for the hybrid layer and resin tag formation.

Results: Groups I and II showed statistically significant difference when the presence/absence of resin tags was compared. When groups III and IV were compared for the presence/

\footnotetext{
${ }^{1-3,5}$ Department of Conservative Dentistry and Endodontics Subbaiah Institute of Dental Sciences, Shimoga, Karnataka India

${ }^{4,6}$ Department of Conservative Dentistry and Endodontics, A.J. Institute of Dental Sciences, Mangaluru, Karnataka, India

Corresponding Author: CN Vijay Kumar, Department of Conservative Dentistry and Endodontics, Subbaiah Institute of Dental Sciences, Shimoga, Karnataka, India, Phone: +919480047110, e-mail: drvijaycn@gmail.com
}

absence of hybrid layer and resin tags, the results were statistically significant.

Conclusion: Between all the four experimental groups, irrespective of the bonding systems used, we concluded that groups with $2 \% \mathrm{CHX}$ usage showed promising results with presence/ absence of hybrid layer and resin tags formation.

Clinical significance: Studies suggest that the bond between composite and dentin degrades over time because of the action of MMPs on collagen fibrils left unprotected by acid etching. Measures should be taken to prevent this from happening and thus allow bond between composite and dentin last longer.

Keywords: Chlorhexidine, Dentin bonding agents, Hybrid layer, Matrix metalloproteinases.

How to cite this article: Vallabhdas AK, Kumar CNV, Kabbinale P, Nayak R, Rajakumari M, Shilpa T. Evaluation of Hybrid Layer and Bonding Interface after Water Storage with and without the Usage of $2 \%$ Chlorhexidine: A Scanning Electron Microscope Study. J Contemp Dent Pract 2018;19(1):52-59.

Source of support: Nil

Conflict of interest: None

\section{INTRODUCTION}

For successful bonding to dentin, it is widely accepted that the formation of a hybrid layer must be achieved through the full infusion of resin monomers into watersaturated acid-etched dentin. The integrity and stability of collagen fibrils are the structural bases for hybrid layer matrices, as well as vital for their durability. The premature degradation of hybrid layers has been associated with the inability of current adhesives to durably seal the dentin substrate. ${ }^{1}$ This abasement process is quite likely to be the consequence of a myriad of factors, including deficient resin monomer infiltration of demineralized dentin and elution of unpolymerized monomers from polymerized adhesives. This results in zones of exposed 
collagen fibrils within hybrid layers that are prone to be attacked by host-derived proteolytic/hydrolytic enzymes. ${ }^{2}$ Evidence of collagenolytic/gelatinolytic activity in dentin demineralized with etch-and-rinse adhesives in the absence of bacteria highlights the potential involvement of host-derived proteases in the disruption of incompletely infiltrated collagen fibrils within hybrid layers. ${ }^{1}$

Long-term dentin bonding is threatened by the disaggregation of the hybrid layer owing mainly to the activation of dentin MMPs. ${ }^{3}$ Host-derived MMPs, found both in saliva and etched dentin, have been shown to be involved in the degradation of the unprotected collagen fibrils within the hybrid layer. ${ }^{3}$ These proteases are secreted by odontoblasts during dentinogenesis and remain inactive within the dentin extracellular matrix. The acidic environment, resulting from adhesive systems or the biologic carious process, activates different dentinal MMPs. ${ }^{4}$ The MMPs are a family of $\mathrm{Zn}$ - and Ca-dependent enzymes that regulate the physiological and pathological metabolism of collagenbased tissues. As in other collagen-based tissues, dentin contains different MMPs: Collagenase MMP-8, gelatinases MMP-2 and -9, stromelysin MMP-3, and enamelysin MMP-20. However, when the dentin matrix mineralizes, MMPs become covered with apatite nanocrystals, making them immobile and nonfunctional. ${ }^{5}$ As long as dentin is mineralized, its proteases remain structurally stable. ${ }^{5}$

It would be advantageous from a clinical perspective to be able to inhibit the breakdown of deficient resinimpregnation collagen fibrils by host-derived MMPs in the dentinal hybrid layer. Tissue inhibitors of metalloproteinases are the major endogenous inhibitors of MMPs. ${ }^{6}$

Chlorhexidine gluconate has been shown to be effective against various oral bacteria. Due to its broad antimicrobial spectrum (i.e., against Gram-positive/ negative bacteria and fungi), CHX has been used to adjunctively treat either endodontic or periodontal diseases and to arrest/prevent caries progression. ${ }^{7}$ Besides its antimicrobial properties, $\mathrm{CHX}$ is applied to treat dentin before the use of etch-and-rinse adhesives to reduce the breakdown of collagen fibrils. ${ }^{3}$ The $\mathrm{CHX}$ has been applied in different sequences, including before etching, after etching (with or without rinsing), or $\mathrm{CHX}$-containing phosphoric acid. Even at low concentration $(0.2 \%), \mathrm{CHX}$ functions as MMPs inhibitor that can prevent bond degradation of collagen and disintegration of the bonding interface. ${ }^{8}$ The use of $0.2 \%$ CHX gluconate for $60 \mathrm{~s}$ was found to inhibit collagenolytic activity thus, maintaining the resin-dentin interface..$^{8-11}$ Pashley et $\mathrm{al}^{8}$ recommended the use of $\mathrm{CHX}$ on acid-etched dentin before using totaletch adhesives. It did not affect the in vitro bond strength of aged specimens tested in microtensile testing, and there were less cohesive failures in dentin or the hybrid layer when dentin was treated with CHX than without such application. ${ }^{12}$ Thus, the aim of this in vitro study is intended to evaluate the effects of $2 \% \mathrm{CHX}$ on hybrid layer and bonding interface.

\section{MATERIALS AND METHODS}

The details of materials used in the study are given in Table 1 . Totally, 40 freshly extracted molars were randomly divided into four experimental groups. In all 40 specimens, class II cavities (mesio-occlusal/distoocclusal) were prepared using a No. 245 carbide bur with a high-speed aerator handpiece under air-water spray in all teeth. Cavities were prepared to a depth of $1 \mathrm{~mm}$ below the dentinoenamel junction with no axial wall, but with elimination of the proximal enamel ridge. The

Table 1: Details of materials used in the study

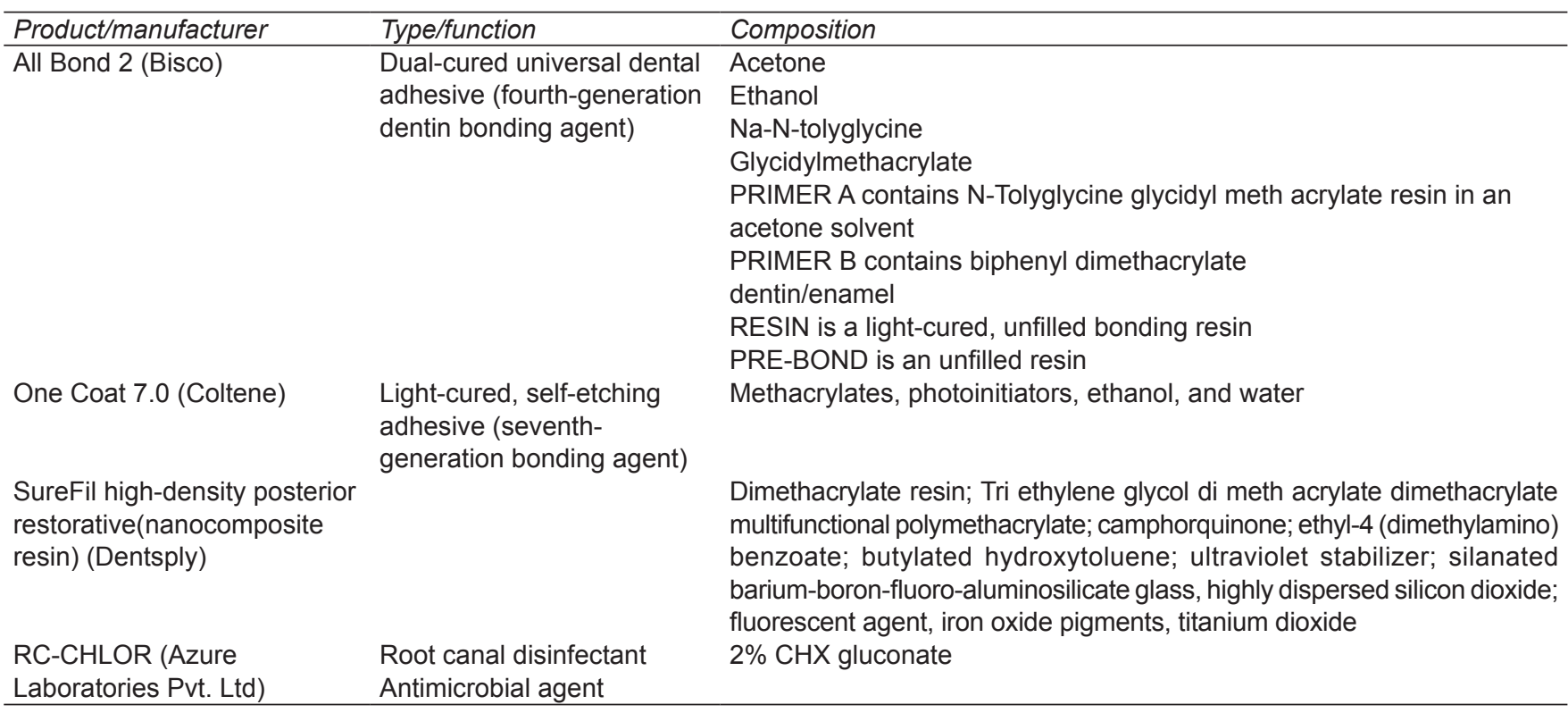


Flow Chart 1: Schematic diagram of methodology

Investigation design

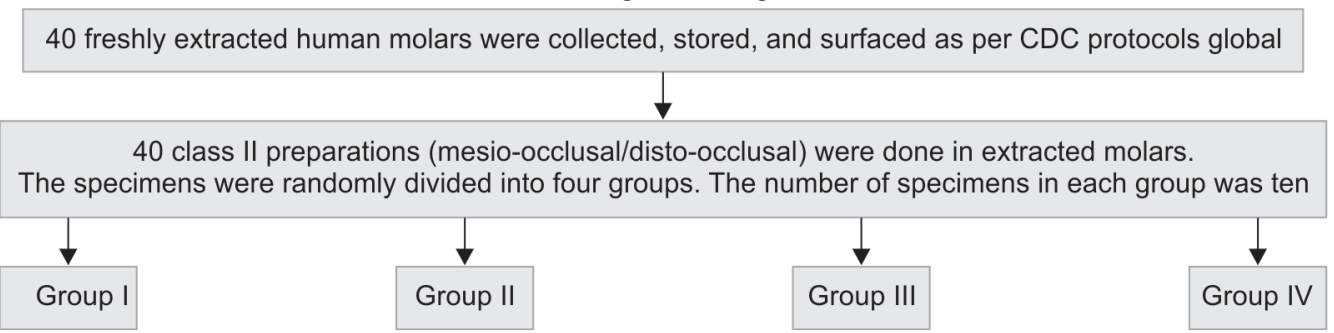

ALL BOND 2 Without 2\% chlorhexidine $(n=10)$
ALL BOND 2 With 2\% chlorhexidine $(n=10)$
ONE COAT7.0 Without $2 \%$ chlorhexidine $(n=10)$
ONE COAT7.0 with $2 \%$ chlorhexidine $(n=10)$

\begin{tabular}{|c|}
\hline Class II \\
preparations \\
+ \\
Etched with \\
$37 \%$ phosphoric acid \\
for 15 seconds \\
+ \\
Rinsed with water for \\
30 seconds and \\
air-dried \\
+ \\
Etched with \\
All Bond2 \\
+ \\
Nanocomposite \\
restoration
\end{tabular}
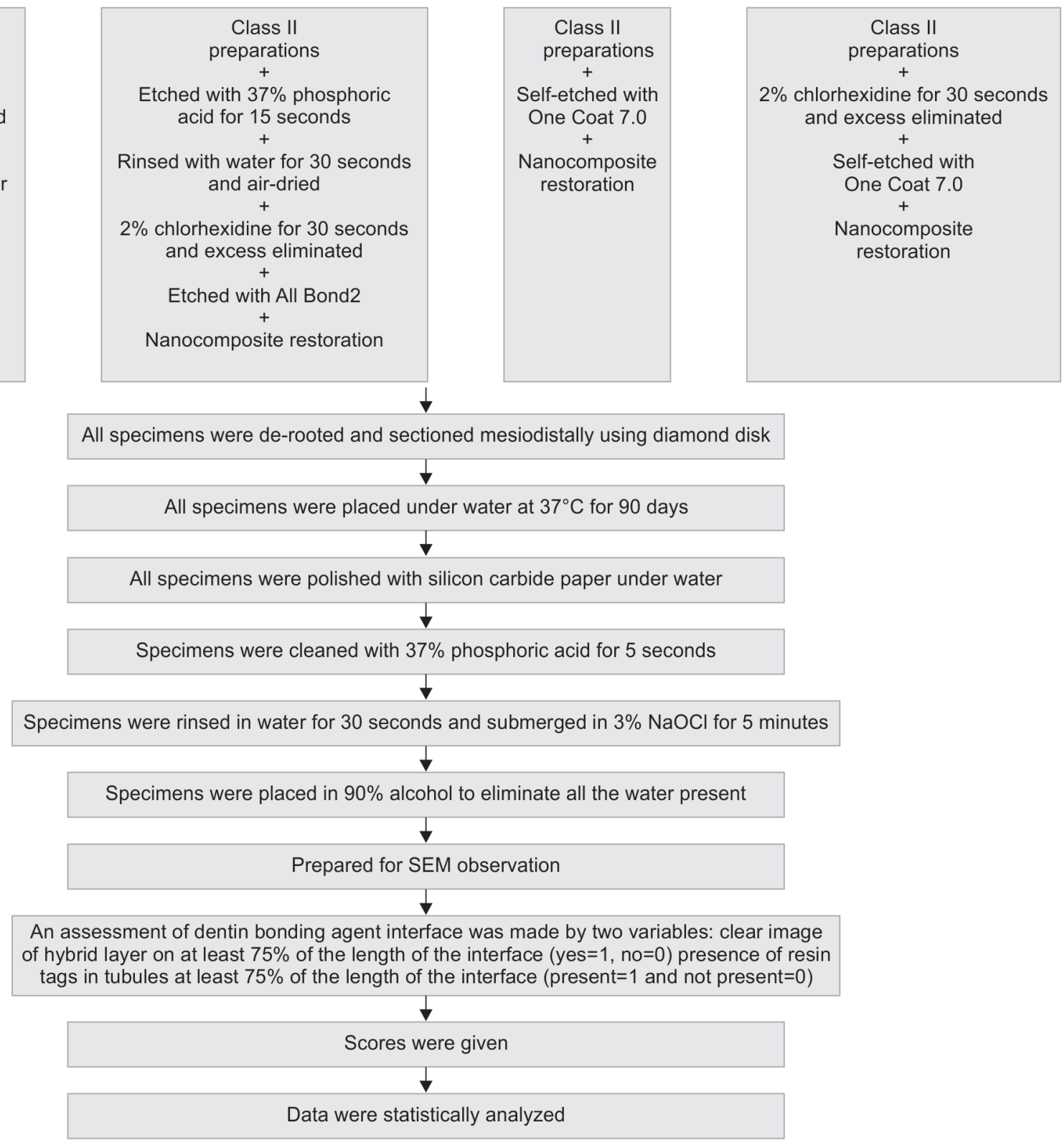

teeth were then randomly divided into four experimental groups (in each group 10, $\mathrm{n}=10$ ), i.e., All Bond 2 without 2\% CHX (group I), All Bond 2 with 2\% CHX (group II), One Coat 7.0 without $2 \%$ CHX (group III), and One Coat
7.0 with $2 \%$ CHX (group IV). All groups were restored with SureFil high-density posterior nanocomposite resin (Dentsply). Schematic diagram of methodology is shown in Flow Chart 1. 
All the specimens were derooted and sectioned mesiodistally into two halves using a low-speed diamond disk (Edenta). Specimens were placed under water at $37^{\circ} \mathrm{C}$ for 3 months. Then, the specimens were prepared for SEM (JOEL Ltd) evaluation. All specimens were polished with silicon carbide paper under water. The specimens were cleaned with 37\% phosphoric acid (Sigma Aldrich) for $5 \mathrm{~s}$, rinsed in water for $30 \mathrm{~s}$, and submerged in $3 \% \mathrm{NaOCl}$ (Prime Dental, India) for 5 minutes. Then, the specimens were placed in 90\% alcohol (Sigma Aldrich) to eliminate all water present before being desiccated and prepared for SEM observation.

All specimens were observed under $\times 800$ magnification, and an assessment of the dentin bonding interface was made by two variables: Clear image of hybrid layer on at least $75 \%$ of the length of the interface (yes $=1$, no $=0$ ) and the presence of resin tags in tubules at least $75 \%$ of the length of the interface (present $=1$, not present $=0$ ). Scores were given for each parameter. This methodology was followed by Lafuente. ${ }^{13}$

\section{RESULTS}

\section{Experimental Groups}

- There was no significant difference in the presence/ absence of hybrid layer between groups I and II (Fig. 1), but groups I and II showed statistically significant difference when the presence/absence of resin tags was compared (Tables 2, 3 and Fig. 2).
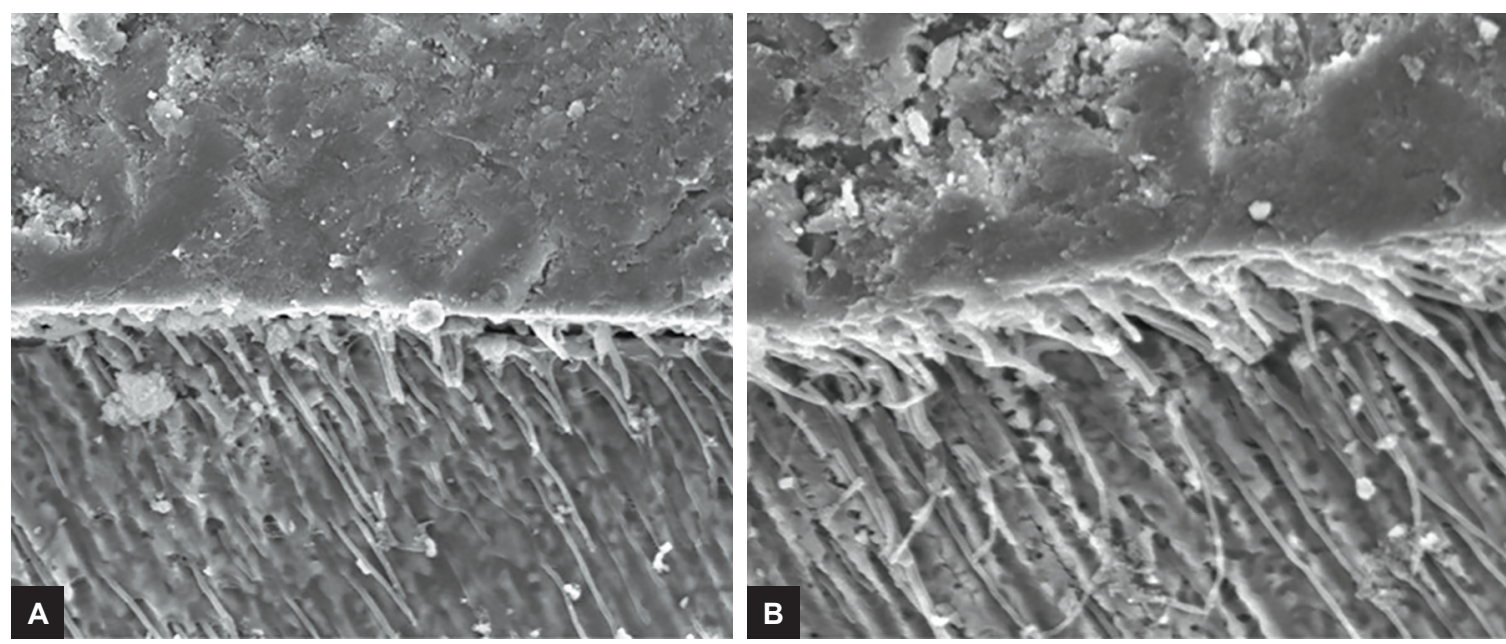

Figs $1 \mathrm{~A}$ and B: The SEM shows no significant difference in the presence/absence of hybrid layer between groups I and II

Table 2: Presence/absence of hybrid layer between the experimental groups

\begin{tabular}{llllll}
\hline & Group I & Group II & Group III & Group IV & \\
\cline { 2 - 5 } & $\begin{array}{l}\text { All Bond 2 without } \\
2 \% \mathrm{CHX}(n=10)\end{array}$ & $\begin{array}{l}\text { All Bond 2 with } \\
2 \% \mathrm{CHX}(n=10)\end{array}$ & $\begin{array}{l}\text { One Coat 7.0 without } \\
2 \% \mathrm{CHX}(n=10)\end{array}$ & $\begin{array}{l}\text { One Coat 7.0 with } \\
2 \% \mathrm{CHX}(n=10)\end{array}$ & Total $(n=40)$ \\
\hline $\begin{array}{c}\text { Absence } \\
\text { Count (\%) }\end{array}$ & $3(30.0)$ & $0(0)$ & $4(40)$ & $0(0)$ & $7(17.5)$ \\
$\begin{array}{c}\text { Presence } \\
\text { Count (\%) }\end{array}$ & $7(70.0)$ & $10(100)$ & $6(60)$ & $10(100)$ & $33(82.5)$ \\
$\begin{array}{c}\text { Total } \\
\text { Count }(\%)\end{array}$ & $10(100.0)$ & $10(100.0)$ & $10(100.0)$ & $10(100.0)$ & $40(100.0)$ \\
\hline
\end{tabular}

$\chi^{2}=8.831 ; p=0.032$ significant

Table 3: Presence/absence of resin tags between the experimental groups

\begin{tabular}{llllll}
\hline & Group I & Group II & Group III & Group IV & \\
\cline { 2 - 4 } & $\begin{array}{l}\text { All Bond 2 without } \\
2 \% \text { CHX }(n=10)\end{array}$ & $\begin{array}{l}\text { All Bond 2 with } \\
2 \% \text { CHX }(n=10)\end{array}$ & $\begin{array}{l}\text { One Coat 7.0 without } \\
2 \% \text { CHX }(n=10)\end{array}$ & $\begin{array}{l}\text { One Coat 7.0 with } \\
2 \% \text { CHX }(n=10)\end{array}$ & Total $(n=40)$ \\
\hline $\begin{array}{c}\text { Absence } \\
\text { Count (\%) }\end{array}$ & $4(40.0)$ & $0(0)$ & $5(50.0)$ & $0(0)$ & $9(22.5)$ \\
$\begin{array}{c}\text { Presence } \\
\text { Count }(\%)\end{array}$ & $6(60.0)$ & $10(100.0)$ & $5(50.0)$ & $10(100.0)$ & $31(77.5)$ \\
$\begin{array}{c}\text { Total } \\
\text { Count }(\%)\end{array}$ & $10(100.0)$ & $10(100.0)$ & $10(100.0)$ & $10(100.0)$ & $40(100.0)$ \\
\hline$\chi^{2}=11.9 ; p=0.008$ & & & & &
\end{tabular}




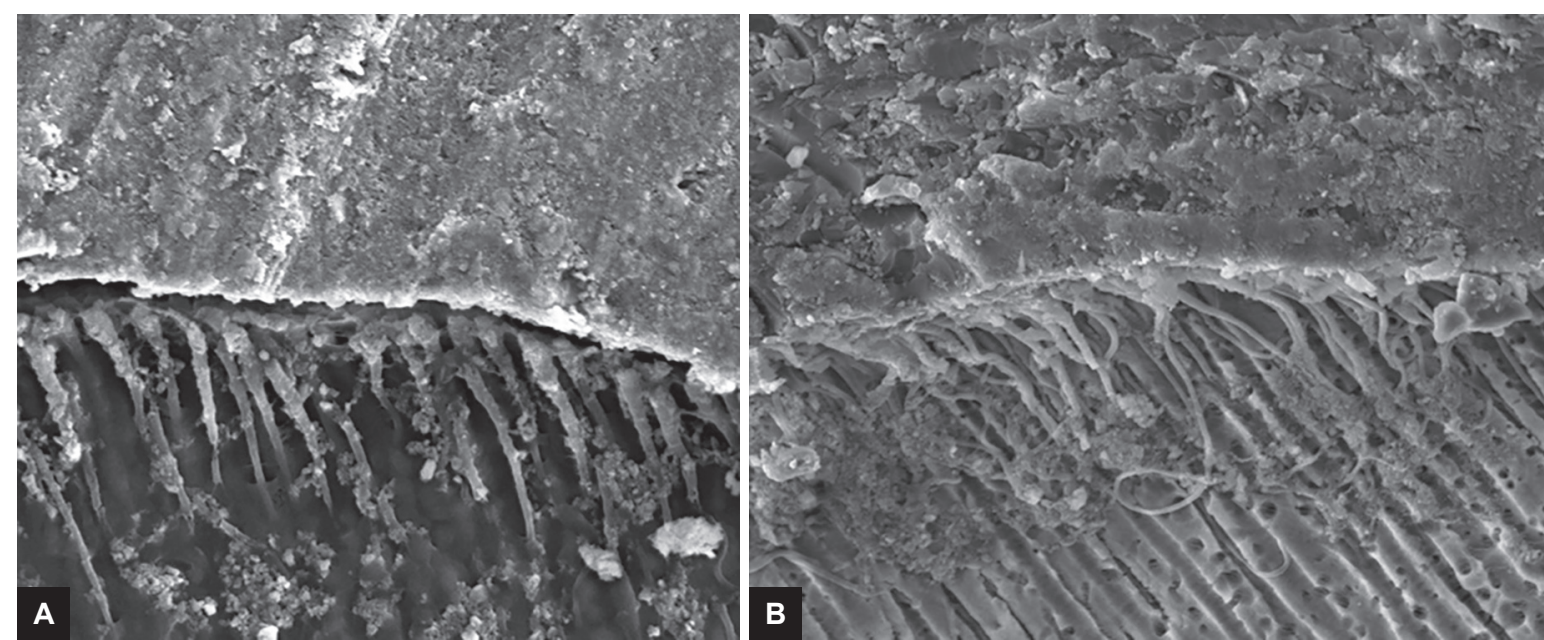

Figs 2A and B: The SEM shows groups I and II have a difference in the presence/absence of resin tags
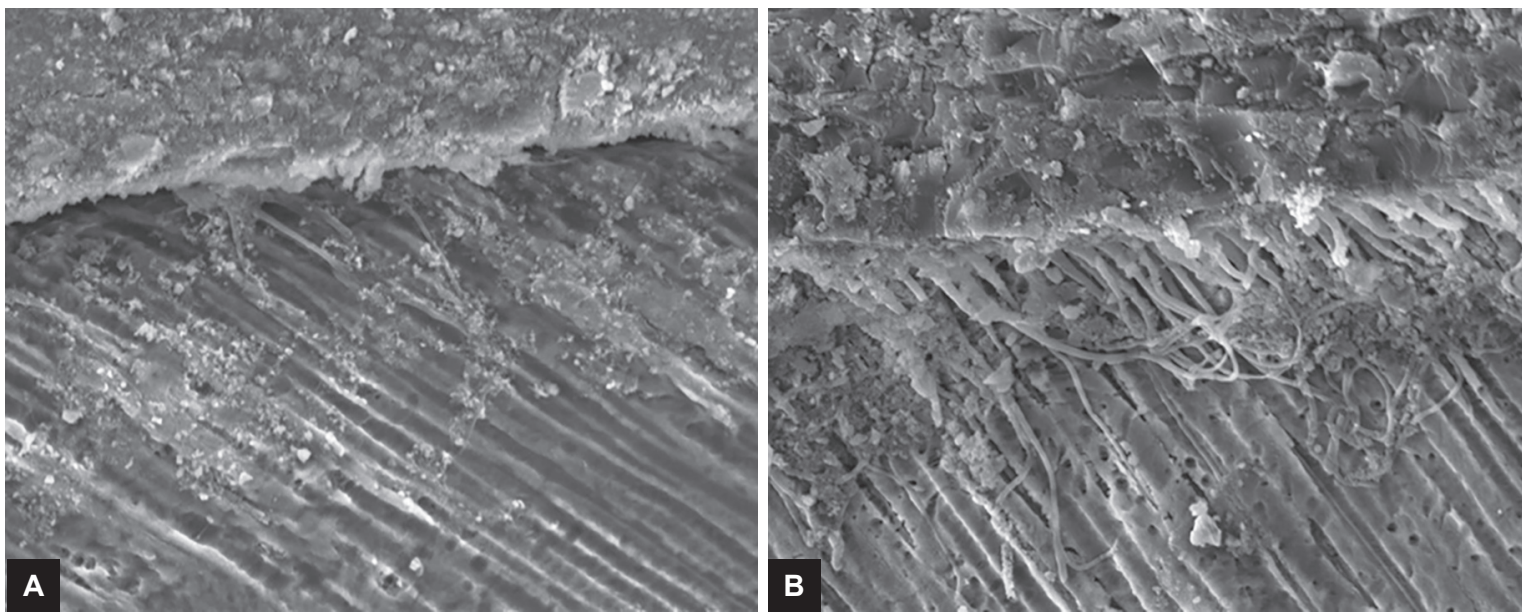

Figs 3A and B: The SEM shows difference in hybrid layer formation between groups III and IV
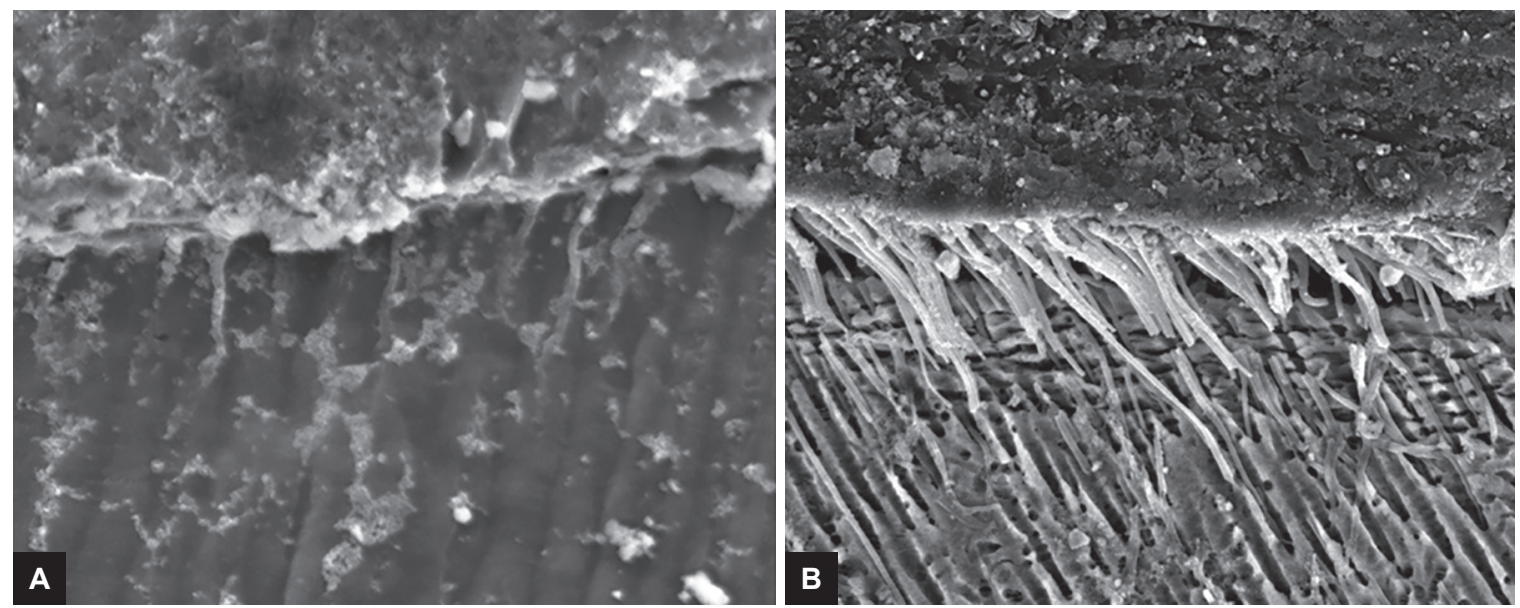

Figs 4A and B: The SEM shows difference in resin tag formation between groups III and IV

- When groups III and IV were compared for the presence/absence of hybrid layer (Fig. 3) and resin tags (Figs 4), the results were statistically significant (Tables 2 to 4 ).

The intercomparison between the four groups for the presence/absence of hybrid layer and resin tags was performed using Mann-Whitney U test (Table 5).
Table 4: Test statistics

\begin{tabular}{lll}
\hline & Hybrid layer & Resin tags \\
\hline Kruskal-Wallis test & 8.610 & 11.602 \\
& 0.035 significance & 0.009 SS \\
\hline
\end{tabular}

SS: Statistically significant

- There was no significant difference in the presence/ absence of hybrid layer between groups I and II, but 
Table 5: Intercomparison between the four groups with and without the use of $2 \% \mathrm{CHX}$ (Mann-Whitney $U$ test)

\begin{tabular}{|c|c|c|c|c|c|c|}
\hline \multirow[b]{2}{*}{ Bonding agents with and without $2 \% \mathrm{CHX}$} & \multicolumn{3}{|c|}{ Hybrid layer } & \multicolumn{3}{|c|}{ Resin tags } \\
\hline & Z-value & $p$-value & Significance & Z-value & p-value & Significance \\
\hline All Bond 2 without $2 \%$ CHX vs All Bond 2 with $2 \% \mathrm{CHX}$ & 1.831 & 0.067 & NS & 2.179 & 0.029 & SS \\
\hline All Bond 2 without $2 \% \mathrm{CHX}$ vs One Coat 7.0 without $2 \% \mathrm{CHX}$ & 0.457 & 0.648 & NS & 0.438 & 0.061 & NS \\
\hline All Bond 2 without $2 \% \mathrm{CHX}$ vs One Coat 7.0 with $2 \% \mathrm{CHX}$ & 1.831 & 0.067 & SS & 2.179 & 0.029 & SS \\
\hline All Bond 2 with $2 \% \mathrm{CHX}$ vs One Coat 7.0 without $2 \% \mathrm{CHX}$ & 2.179 & 0.029 & SS & 2.517 & 0.012 & SS \\
\hline All Bond 2 with $2 \% \mathrm{CHX}$ vs One Coat 7.0 with $2 \% \mathrm{CHX}$ & 0 & 1 & NS & 0 & 1 & NS \\
\hline One Coat 7.0 without $2 \% \mathrm{CHX}$ vs One Coat 7.0 with $2 \% \mathrm{CHX}$ & 2.179 & 0.029 & SS & 2.517 & 0.012 & SS \\
\hline
\end{tabular}

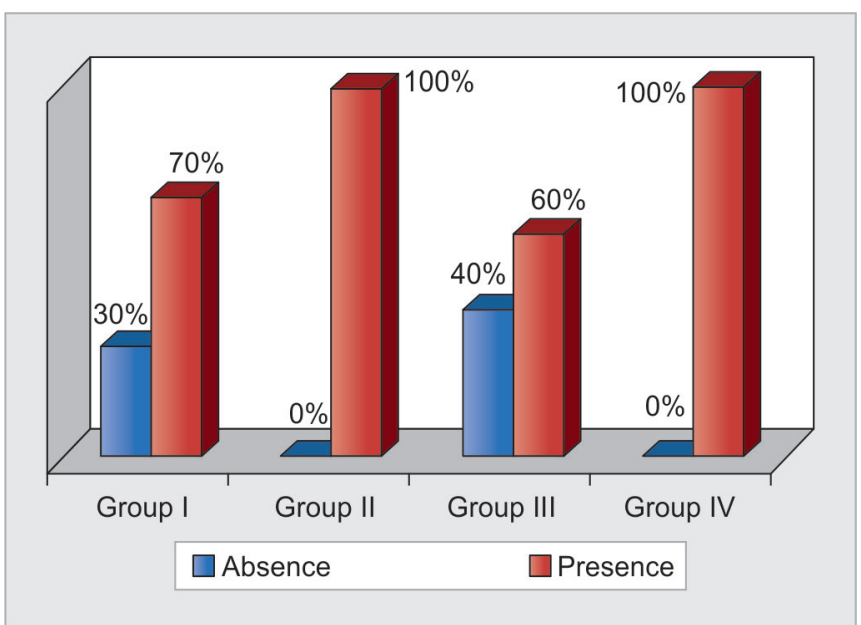

Graph 1: Presence/absence of hybrid layer between the groups $(n=40)$

groups I and II showed a statistically significant difference when the presence/absence of resin tags was compared (Graphs 1 and 2).

- When groups I and III were compared for the presence/absence of hybrid layer and resin tags, the results were not statistically significant (Graphs 1 and 2).

- When groups I and IV were compared for the presence/absence of hybrid layer and resin tags, the results were statistically significant (Graphs 1 and 2).

- When groups II and III were compared for the presence/absence of hybrid layer and resin tags, the results were statistically significant (Graphs 1 and 2).

- When groups II and IV were compared for the presence/absence of hybrid layer and resin tags, the results were not statistically significant.

- When groups III and IV were compared for the presence/absence of hybrid layer and resin tags, the results were statistically significant.

\section{DISCUSSION}

Enamel bonding adhesives have a long track record, and the process is very well understood after years of research beginning with Buonocore and probably still continuing with Bowen et al. ${ }^{14}$ Dentin has been characterized

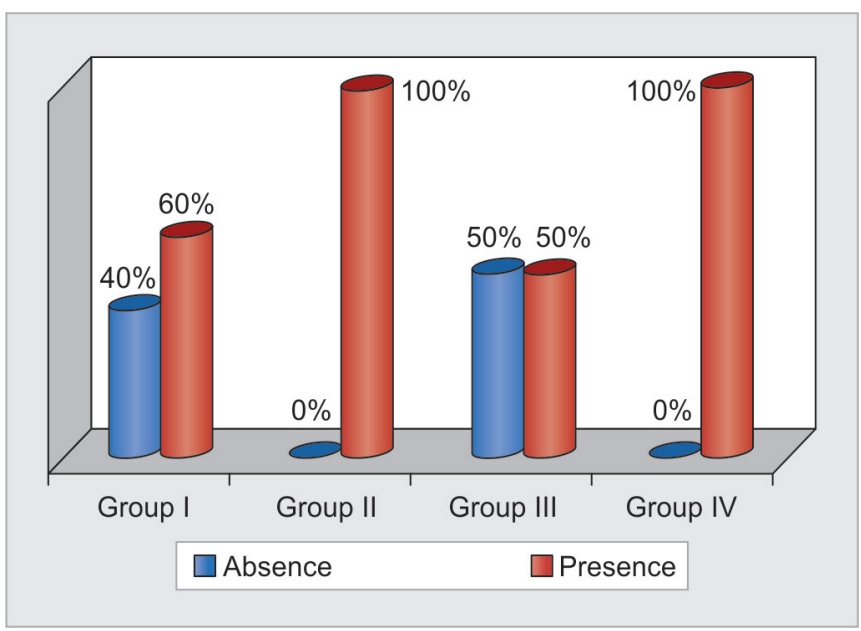

Graph 2: Presence/absence of resin tags between the groups

as a biologic composition of collagen matrix filled with submicron- to nanometer-sized, calcium-deficient, and carbonate-rich appetite crystals dispersed between parallel micron-sized hypermineralized collagen-poor hollow cylinders. Pashley and Carvalho ${ }^{14}$ speculated that regional differences in dentinal tubules density, dentin permeability, calcium concentration, presence of abnormal dentin, varying smear layer thickness, result in nonuniform resin infiltration into the collagen fibrils of intertubular dentin thus, leading to nonuniform bond strength values.

Most laboratory researchers have time and again indicated that there is a premature loss of bond strength, which affects adhesive restorations, due to degradation of the hybrid layer at the dentin-adhesive interface and deterioration of dentin collagen fibrils. ${ }^{11}$

The CHX, though a controversial antiseptic today, remains a gold standard as an antiplaque agent, and its efficacy in caries prevention is clinically well documented. Studies done with SEM and other methods have conclusively proved that $\mathrm{CHX}$ is found to be an MMPs' inhibitor, preserving the humidity necessary for keeping the collagen network expanded. ${ }^{15}$

Tjäderhane et $\mathrm{al}^{16}$ mentioned that endogenous dentin collagenolytic enzymes, MMPs, and cysteine cathepsins are responsible for time-dependent hydrolysis of collagen 
matrix of hybrid layers. He further stated that as collagen matrix integrity is essential for the preservation of longterm dentin bond strength, inhibition of endogenous dentin proteases is necessary for durable resin-bonded restorations. ${ }^{16}$ The vast majority of the experiments aimed to improve the durability of dentin bonds using enzyme inhibition have been performed with CHX, a potent antimicrobial agent. The $\mathrm{CHX}$ inhibits effectively MMPs-2, -9 , and $-8 .^{16}$

Moon et $\mathrm{al}^{11}$ discussed the effect of hybrid-dentin bond layer stability and use of CHX to prevent bond failure. He states that application of acid resins of dentinbonding agents, after the activation is depleted by the phosphoric acid etchant in the etch-and-rinse bonding agents, more than restores the MMPs activity in dentin. In addition, activated MMPs may find their way to leakage at bond gaps from MMPs in saliva, crevicular fluid, and through dentinal tubule fluid from the pulp over a time. If collagen fibrils are left exposed in the hybrid layer, unprotected by resin, they can be degraded by the activated MMPs. This degradation in vitro may show as loss of retention clinically or a decrease in bond strength.

In the present study, we utilized two main groups, All Bond 2 representing the fourth-generation bonding system and One Coat 7.0 representing the seventh-generation bonding system with and without application of 2\% CHX gluconate.

Based on the statistical results analyzed, there was no statistical difference in the presence/absence of hybrid layer between groups I and II, but groups I and II showed statistically significant difference when the presence/ absence of resin tags were compared. When groups III and IV were compared for the presence/absence of hybrid layer and resin tags, the results were statistically significant. Pashley and Carvalho. ${ }^{14}$ studied the deterioration of hybrid layer due to aging and came to a conclusion that there is deterioration of hybrid layer after water storage. This is in agreement with the study done by Lafuente. ${ }^{13}$ In the present study, the effect of water storage on the hybrid layer produced a reduction in thickness of hybrid layer, and it was difficult to isolate the hybrid layer in some of the samples that were not pretreated with $2 \%$ CHX. Gendron et $\mathrm{al}^{17}$ as early as in 1999 , stated that there is complete inhibition of MMP-2 and -9 gelatinase activity with $\mathrm{CHX}$ concentrations as low as $0.03 \%$. In this study, $2 \% \mathrm{CHX}$ is used as disinfecting solution to acid-etched dentin before the use of total-etch adhesives. This can have additional potential merits in preventing the degradation of collagen fibrils in the dentin-hybrid layers.

According to Liu et $\mathrm{al}^{2}$ there were two major mechanisms involved in the degradation of resin-dentin bonds over time. One mechanism is slow hydrolysis of resin components caused by water sorption or esterases. The other is degradation of water-rich, resin-sparse collagen fibrils within the hybrid layers by the activation of hostderived MMPs and possibly cysteine cathepsins during bonding procedures. They state that complete replacement of free and loosely bound water within the collagen water compartments and inactivation or silencing the collagenolytic enzymes appeared to be the ultimate goals for comparing the durability of resin-dentin bonds.

According to Tjäderhane et al, ${ }^{16}$ enzyme inhibition with CHX is to improve the durability of dentin bonds and reduce time-dependent reduction in dentin bond strength.

Some studies have also revealed that the topical application of CHX after acid etching has no effect on the immediate bond strength. ${ }^{18-22}$ Dutra-Correa et $\mathrm{al}^{23}$ reported that the application of $\mathrm{CHX}$ before the application of dentin adhesives did not influence their clinical performance up to 18 months of service.

The results of the present study are in agreement with the studies done by several authors including Lafuente, ${ }^{13}$ Gendron et $\mathrm{al}^{17}$ and Liu et $\mathrm{al}^{2}{ }^{2}$ In the present study, we have only looked into one parameter to increase the service life of the resin-based bonding procedure. There are many other factors that the authors have recommended, including the use of broad-spectrum inhibitors of collagenolytic enzymes, ethanol-wet bonding with hydrophobic resins, as well as biomimetic remineralization of water-filled collagen matrix using analogs of matrix proteins to progressively replace water with intraand extrafibrillar appetites to exclude exogenous collagenolytic enzymes. ${ }^{2}$ Most authors have recommended a combination of several of these strategies that would result in overcoming the critical barrier to progress, i.e., currently encountered in dentin bonding.

More studies are required to combine all the factors involved in dentin bonding to come to a conclusion as to what helps in resin-dentin bonding.

\section{CONCLUSION}

Under the conditions of this in vitro study:

- On comparison between the groups where the fourthgeneration bonding system (All Bond 2) was used, the group with $2 \% \mathrm{CHX}$ showed better results when the presence/absence of resin tags were compared, whereas there was no significant difference in presence/absence of hybrid layer between the groups.

- When groups III and IV were tested with seventhgeneration bonding system (One Coat 7.0), group with $2 \% \mathrm{CHX}$ showed statistically significant results in comparison with group without $2 \% \mathrm{CHX}$ when compared for the presence/absence of hybrid layer and resin tags. 
- However, on overall comparison between all the four experimental groups, irrespective of the bonding systems used, we concluded that groups with $2 \%$ CHX usage showed promising results with presence/ absence of hybrid layer and resin tags formation.

\section{REFERENCES}

1. Carrilho MR, Tay FR, Donnelly AM, Agee KA, Tjäderhane L, Mazzoni A, Breschi L, Foulger S, Pashley DH. Host-derived loss of dentin matrix stiffness associated with solubilization of collagen. J Biomed Mater Res B Appl Biomater 2009 Jul;90(1):373-380.

2. Liu Y, Tjäderhane L, Breschi L, Mazzoni A, Li N, Mao J, Pashley DH, Tay FR.. Limitations in bonding to dentin and experimental strategies to prevent bond degradation. J Dent Res 2011 Aug;90(8):953-968.

3. Zhang SC, Kern M. The role of host-derived dentinal matrix metalloproteinases in reducing dentin bonding of resin adhesives. Int J Oral Sci 2009 Dec;1(4):163-176.

4. Almahdy A, Koller G, SauroS, Bartsch JW, Sherriff M, Watson TF, Benerjee A. Effects of MMP inhibitors incorporated within dental adhesives. J Dent Res 2012 Jun;91(6):605-611.

5. Mazzoni A, Scaffa P, Carrilho M, Tjäderhane L, Di Lenarda R, Polimeni A, Tezvergil-Mutluay A, Tay FR, Pashley DH, Breschi L. Effects of etch-and-rinse and self-etch adhesives on dentin MMP-2 and MMP-9. J Dent Res 2013 Jan;92(1):82-86.

6. Balaji H. MMP inhibitors-a review. Int J Pharm Sci Health Care 2017 Mar-Apr;7(2):45-56.

7. Carrilho MR, Carvalho RM, Sousa EN, Nicolau J, Breschi L, Mazzoni A, Tjäderhane L, Tay FR, Agee K, Pashley DH. Substantivity of chlorhexidine to human dentin. Dent Mater 2010 Aug;26(8):779-785.

8. Pashley DH, Tay FR, Yiu C, Hashimoto M, Breschi L, Carvalho RM, Ito S. Collagen degradation by host-derived enzymes during aging. J Dent Res 2004 Mar;83(3):216-221.

9. Breschi L, Martin P, Mazzoni A, Nato F, Carrilho M, Tjäderhane L, Visintini E, Cadenaro M, Tay FR, De Stefano Dorigo E, et al. Use of a specific MMP-inhibitor (galardin) for preservation of hybrid layer. Dent Mater 2010 Jun;26(6):571-578.

10. Hashimoto M, Ohno H, Sano H, Kaga M, Oguchi H. In vitro degradation of resin-dentin bonds analyzed by microtensile bond test, scanning and transmission electron microscopy. Biomaterials 2003 Sep;24(21):3795-3803.

11. Moon PC, Weaver J, Brooks CN. Review of matrix metalloproteinases' effect on the hybrid dentin bond layer stability and chlorhexidine clinical use to prevent bond failure. Open Dent J 2010 Jul;4:147-152.

12. deCastro FL, de Andrade MF, Duarte Júnior SL, Vaz LG, Ahid FJ. Effect of $2 \%$ chlorhexidine on microtensile bond strength of composite to dentin. J Adhes Dent 2003 Summer;5(2):129-138.

13. Lafuente D. SEM analysis of hybrid layer and bonding interface after chlorhexidine use. Oper Dent 2012 Mar-Apr;37(2):172-180.

14. Pashley DH, Carvalho RM. Dentine permeability and dentine adhesion. J Dent 1997 Sep;25(5):355-372.

15. Mazzoni A, Pashley DH, Nishitani Y, Breschi L, Mannello F, Tjäderhane L, Toledano M, Pashley EL, Tay FR. Reactivation of inactivated endogenous proteolytic activities in phosphoric acid-etched dentine by etch-and-rinse adhesives. Biomaterials 2006 Sep;27(25):4470-4476.

16. Tjäderhane L, Nascimento FD, Breschi L, MazzoniA, Tersariol IL, Geraldeli S, Tezvergil-Mutluay A, Carrilho MR, Carvalho RM, Tay FR, et al. Optimizing dentin bond durability: Control of collagen degradation by matrix metalloproteinases and cysteine cathepsins. Dent Mater 2013 Jan;29(1):116-135.

17. Gendron R, Grenier D, Sorsa T, Mayrand D. Inhibition of the activities of matrix metalloproteinases 2,8 , and 9 by chlorhexidine. Clin Diagn Lab Immunol 1999 May;6(3):437-439.

18. Carrilho MR, Geraldeli S, Tay F, de Goes MF, Carvalho RM, Tjäderhane L, Reis AF, Hebling J, Mazzoni A, Breschi L. et al. In vivo preservation of the hybrid layer by chlorhexidine. J Dent Res 2007 Jun;86(6):529-533.

19. Breschi L, Mazzoni A, Nato F, Carrilho M, Visintini E, Tjäderhane L, Ruggeri A Jr, Tay FR, Dorigo Ede S, Pashley DH. Chlorhexidine stabilizes the adhesive interface: a 2-year in vitro study. Dent Mater 2010 Apr;26(4):320-325.

20. Brackett MG, Tay FR, Brackett WW, Dib A, Dipp FA, Mai S, Pashley DH. In vivo chlorhexidine stabilization of hybrid layers of an acetone-based dentin adhesive. Oper Dent 2009 Jul-Aug;34(4):379-383.

21. Komori PC, Pashley DH, Tjäderhane L, Breschi L, Mazzoni A, de Goes MF, Wang L, Carrilho MR. Effect of $\%$ chlorhexidine digluconate on the bond strength to normal versus cariesaffected dentin. Oper Dent 2009 Mar-Apr;34(2):157-165.

22. Loguercio AD, Stanislawczuk R, Polli LG, Costa JA, Michel $\mathrm{MD}$, Reis A. Influence of chlorhexidine digluconate concentration and application time on resin-dentin bond strength durability. Eur J Oral Sci 2009 Oct;117(5):587-596.

23. Dutra-Correa $\mathrm{M}$, Saraceni $\mathrm{CH}$, Ciaramicoli MT, Kiyan VH, Queiroz CS. Effect of chlorhexidine on the 18-month clinical performance of two adhesives. J Adhes Dent 2013 Jun;15(3): 287-292. 